\title{
TRADE PRACTICES OF RETAIL CHAINS AS FAR AS THE TRANSACTION COST ANALYSIS IN RELATIONSHIPS MANUFACTURER - RETAILER ARE CONCERNED
}

\author{
Jaroslav Kita $^{1}$, Katarína Máziková ${ }^{2}$, Marta Grossmanová $^{3}$, Pavol Kita ${ }^{4}$ \\ University of Economics in Bratislava, Dolnozemská cesta 1, 85235 Bratislava, Slovakia \\ E-mails: ${ }^{1}$ jaroslav.kita@euba.sk; ${ }^{2}$ katarina.mazikova@euba.sk; \\ ${ }^{3}$ marta.grossmanova@euba.sk; ${ }^{4}$ pavol.kita@euba.sk (corresponding author)
}

Received 26 July 2011; accepted 11 November 2011

\begin{abstract}
Paper is based on the knowledge of the theory of transaction cost analysis, which makes it possible for the members of the distribution channel to make decisions on the number of forms of the organization in order to realize their activities successfully. That explains the functioning of the relations on the basis of the transaction costs theory and helps understand how the retail chain makes its decisions with the aim of lowering the costs resulting from its activity with regard to its own strategic goals in the context of cooperation with the milk producer. In this framework and using the example of milk, the article shows the trade practices of retail chains to improve the relationships manufacturer - retailer in the Slovak consumer market.
\end{abstract}

Keywords: manufacturer-retailer relationship, retail chain, purchasing department, transaction cost analysis, milk products, Slovak food market.

JEL Classification: D23, D43.

\section{MAŽMENINĖS PREKYBOS TINKLŲ VEIKLOS PRAKTIKA ANALIZUOJANT SANDORIO IŠLAIDAS, SUSIJUSIAS SU GAMINTOJU: MAŽMENININKO RŪPESTIS}

\author{
Jaroslav Kita ${ }^{1}$, Katarína Máziková ${ }^{2}$, Marta Grossmanová $^{3}$, Pavol Kita ${ }^{4}$ \\ Bratislavos ekonomikos universitetas, Dolnozemská cesta 1,852 35 Bratislava, Slovakija \\ El.paštas: ${ }^{1}$ jaroslav.kita@euba.sk; ${ }^{2}$ katarina.mazikova@euba.sk; \\ ${ }^{3}$ marta.grossmanova@euba.sk; ${ }^{4}$ pavol.kita@euba.sk
}

Iteikta 2011-07-26; priimta 2011-11-11

\begin{abstract}
Santrauka. Straipsnis parengtas remiantis žiniomis apie sandorio išlaidų analizės teoriją, kuri leidžia paskirstymo kanalo dalyviams priimti sprendimus dèl organizavimo formų, siekiant sèkmingos ju veiklos. Teorija paaiškina, kuo grindžiami santykiai tarp dalyvių, ir padeda suprasti, kaip mažmeninès prekybos tinklas priima sprendimus siekdamas sumažinti išlaidas. Šios išlaidos patirtos dèl veiklos nustatant strateginius tikslus bendradarbiavimo su pieno gamintojais kontekste. Vadovaujantis tokiu požiūriu ir pieno produktų pavyzdžiu, straipsnyje atskleidžiama mažmeninės prekybos tinklų veiklos praktika, siekiant pagerinti santykius tarp gamintojų ir mažmenininkų Slovakijos maisto produktų rinkoje.
\end{abstract}

Reikšminiai žodžiai: gamintojo mažmenininko santykiai, mažmeninės prekybos tinklas, pirkimų dalinys, sandorio išlaidụ analizé, pieno produktai, Slovakijos maisto produktų rinka. 


\section{Introduction}

The present situation of the relations between the Slovak producers of food products and retailers can be characterized from two points of view. The first one is related to the situation of farmers in the Slovak economy, which is connected with the decline of the share of agriculture in creation of GNP, intensive competition in this sector, low efficiency of enterprises, obsolete technical equipment, problematic allocation of subsidies, non-functioning of the market with soil, unsettled ownership relations, and the like (Grznár et al. 2009). The second one fastens on to the first one and describes the situation of the retailers in negotiating the purchase of milk with their suppliers more in detail. The retailers face the surplus of food products as the farmers are not able to export the products produced and at the same time they face the offer of cheaper products by foreign producers which results in an extensive import. Moreover, their situation is complicated by such factors as rapid changes in weather, low trust in the future of agricultural policy in the European Union, irregularities in consumption of agricultural products by consumers as well as the growth of costs, which results in market instability. These obstacles make the retail chains in their negotiations with their suppliers use different practices with the aim of ensuring the functioning of distribution channel. This is connected with a generally known problem of service charges, which the retailer grants the supplier (e.g. listing prices, backbuying of the unsold goods at the same price, high penalties in the case of delayed deliveries, growth rebates, and the like), or sharing the costs and risks needed to develop new products and markets (e.g. leaflet promotion and the like). This results in the conflict between the members of the distribution channel, i.e. the producer and retailer as the additional payments or the contractual penalties make the creation of the supplier's margin less transparent whilst this problem has not been properly analyzed so far.

Therefore the primary purpose of this article is to discuss the trade practices used by retail chains from the point of view of the possible solutions of conflicts between the members of the distribution channel, which have an influence on the selling prices for end users.

The paper explains the functioning of the relations on the basis of the transaction costs theory and helps understand how the retail chain makes its decisions with the aim of lowering the costs resulting from its activity with regard to its own strategic goals in the context of cooperation with the milk producer. The article is targeted at milk which is at present the main component of healthy catering and healthy nutrition. This fact is also taken into account by e.g. retail chain Tesco by promoting the milk sale in the milk vending machine network. We can say that in their strategies the retail chains are increasing their interest in milk with the aim of extending the possibilities of milk offer, which makes this product a strategic priority within their assortment for many retail chains and at the same time they are trying to improve their market position within the healthy nutrition and support the local producers of milk (Sedlák, Kucejová 2010).

Using the example of milk being sold by the retail chains, the article shows the groundwork of the retail chains practices from the point of view of transaction cost analysis with the aim of improving the relations producer - retailer. The subject matter of the research is as follows:

- the theoretical aspects of transaction costs;

- the place of the purchasing department within the relations retailer-supplier from the point of view of transaction;

- the need to make use of the transaction costs theory in creation of new theoretical knowledge on the basis of analysis of present situation of the producer - retailer relations.

\section{Theoretical aspects of the transaction costs}

On the basis of different environmental factors which influence the relations between a producer and retailer in the purchase sphere, the retail chains carry out the activities for their better managing. These activities of chains can be explained on the basis of the approach based on the transaction cost theory and the vertical integration of R. Coase (Rindfleisch, Heide 1997). This theory is the subject matter of many applications with the aim of explaining the existence of different organizational forms related to two places of activity regulation: free market or hierarchical relation. A decision maker must make a compromise between the transactions which he/she makes and find a balance between those which give more advantages to prefer the market and those which give more advantages to prefer the integrated organization (hierarchical relations). There is a hierarchical relation because the orientation at the market can be costly for a decision maker and it causes transaction costs (costs connected with forming the adequate prices, costs connected with business negotiation, with concluding an agreement with other participants of the distribution channel, with control of agreements and the like). In other words, every activity exists due to the failure of another activity. The market and the hierarchical relation as the two places of the regulation of activates are connected with the mechanisms of coordination. The coordination function in the market is carried out by the price mechanism and within the hierarchical relation, it is the retail chain coordinator's authority which may be replenished by partnership and trust.

The works of O. E. Williamson (Heide 1994) have elaborated the R. Coase's proposals which are taking into consideration the costs in the relationship management and 
the possibility of rise of occasional costs resulting from the wrong decisions made. The O. E.Williamson's approach is specified by micro analytical framework based on the interplay between two presumptions of human behavior, i.e. the limited rationality and the behavior targeted at seeking the opportunities and the two main characteristics of transaction, i.e. the information asymmetry and the socio-economic environment (Rosenbloom 1999).

The theory of transaction costs tries to explain the choice of the right partner of the distribution channel on the basis of the main principle, i.e. the minimization of costs which arise in the exchange within the retail chain. From this point of view the specific activities of the purchasing department of the relevant chain within cooperation with the producer point at different forms of distribution channels active in the Slovak consumer market. This makes us consider the retailer's power in his relation with producer, which results in the conflict and the protection strategies of producers in the distribution channel in creating and accommodating the value in their offer that results from the frequency of the transaction realizations. The above also explains the development of approaches such as the management of product groups (category marketing) and trade marketing of producer (trade marketing) that emphasize the need of searching the cooperation aspect within the distribution channel while the retailer's success is presented as being dependent on suppliers because their marketing activities depend on the partner's contribution with the aim of creating a long-term relationship whilst the power is being substituted by trust and partnership. In the same way, the efficiency of the relevant distribution channel will depend on the abilities of a producer and retailer to equally share the costs of each activity connected with managing the distribution channel. This way the distribution can be defined as a source of lowering the costs by means of a common orientation at the consumer's requirements and at the same time the main approach to the creation of normative organization.

Figure 1 illustrates the organization of relations in the distribution channel, either on the basis of market, i.e. the market exchange or on the basis of hierarchical relation which is represented by vertical integration.

Figure 1 shows three situations of the producer-retailer relationship. The first situation presents the traditional model when a producer supplies a retailer with a product and decides the features and price of the product. This traditional model is characterized by the changing level of sale and creates conflicts between the producer and retailer as for the charges paid by a producer to a retailer. The second situation illustrates the model of cooperation relations between a retailer and producer. In this case, i.e. in the case of hybrid integration between a retailer and producer, the concept of product is a result of cooperation between a producer and retailer and indirectly influences also the basic producer.

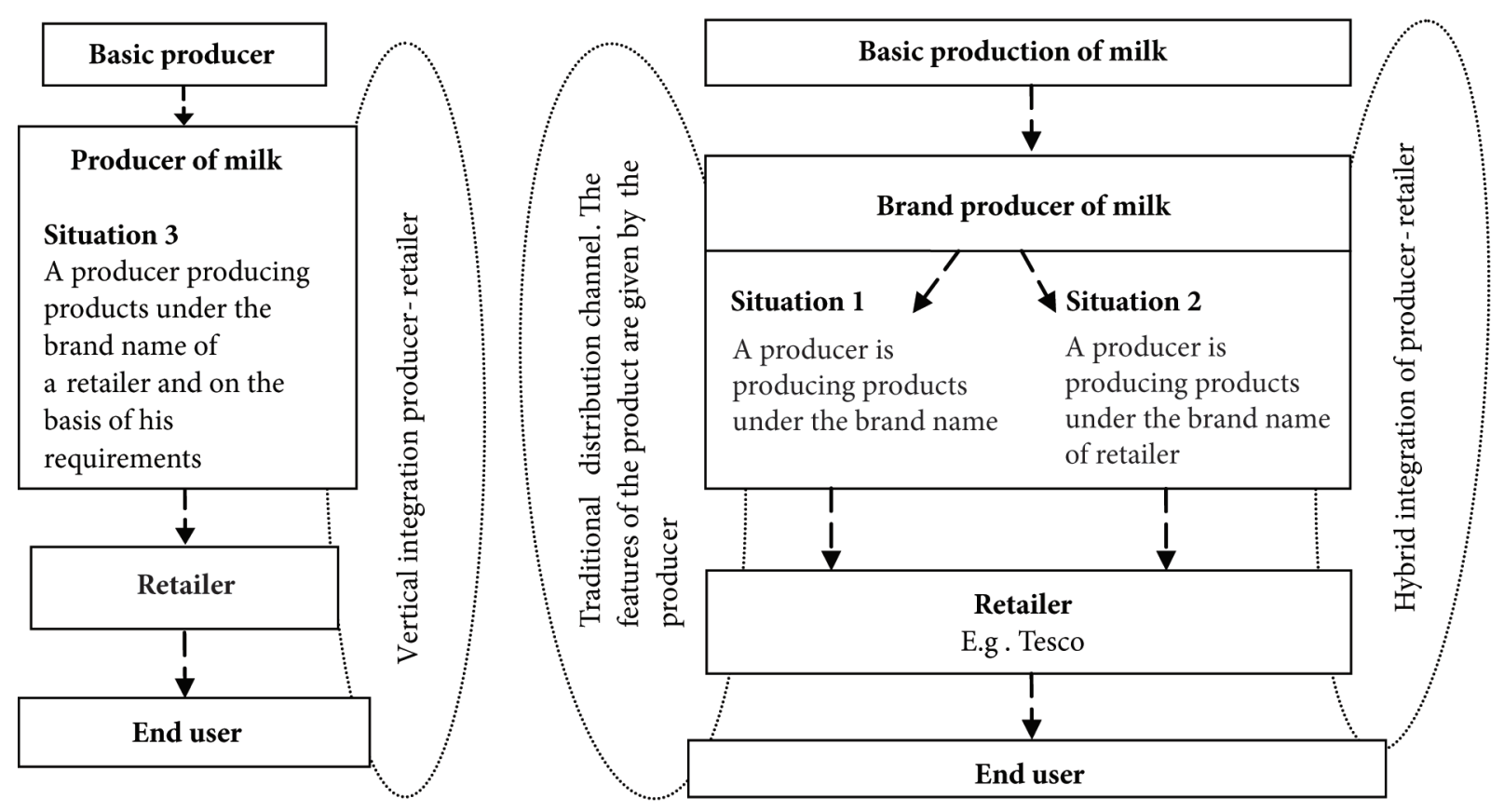

Source: our own procession of the issue

Fig. 1. Different situations of organization of the distribution channel between the producer and retailer 
The producer accepts the requirements of a retailer concerning the product and allows the retailer to be in charge of the sales. The third situation presents the case of vertical integration within which a retailer asks a producer to supply him with the goods according to his requirements whilst the transfer of information is made in a vertical way. Such a connection between a producer and retailer corresponds with the cooperation strict sense when the producer only meets the requirements of a retailer.

\section{The basic attributes of transaction costs}

Fastening on to the analysis of R. Coase, on the basis of considering the transaction costs $\mathrm{O}$. E. Williamson is trying to answer the question: in which cases the company prefers market (agreement relations) and in which cases they prefer the hierarchical relation (integrated organization).

He differentiates between the following attributes of transaction between a producer and retailer: a conditional transaction attribute, which is given by the existence of a hierarchical relation and unconditional transaction attributes which are related to the specific assets, environment uncertainty and uncertainty in behavior.

The hierarchical relation is such an organization of activities which replaces the price system by a set of rules which are decreasing the risks connected with the human behavior. The task of internalization of activities within the hierarchical relation is not to eliminate the influence of the market but rather to modify its boundaries. The market and contractual transactions are being transformed to the managed transactions on the basis of the system of agreements between the members of integrated organization which leads e.g. to a consensus in creating the deliveries. The transaction organization costs within the hierarchical relation (control, coordination, supervision and the like) are lower than the profit which is caused by the internalization of activities within the chain (Anderson 1988).

Specific assets are related to the transferable and nontransferable assets, vicinity of production, specific human resources, brand name, customer loyalty, and the like (Baudry 1995). The owners of these assets are interested in continuing the relations for as long as possible because in majority of cases they can be applied only to a small extent. The contractual parties can take post contractual behavior orientated at seeking the opportunities and in some transactions they are able to profit from the given situation.

Environmental uncertainty in the sphere of transaction cost analysis is related to the unexpected changes in the circumstances connected with exchange. As for measuring, the environmental uncertainty seems to be the most problematic aspect of all attributes. There are two mutually competing points of view of management of activities. The most general one is the attitude of hold up, which emphasizes the unpredictability of the character of external environment whilst the second one analyzes two aspects - the unpredictability and complexity of environment. This is connected with the environmental turbulence, i.e. its complexity and volatility as well as the threatening in the business sphere in individual markets. The term environmental uncertainty is also connected with the technological lagging behind or unexpected technological development. The environmental uncertainty cannot be understood only in a negative way because it also contributes to the creation of more perfect contractual relations between a producer and retailer. This effect is characterized by its dynamism and complexity in creation of different relation structures as far as the perception of environmental uncertainty by the managers of retailers and producers is concerned. The further indicators of environmental uncertainty are also the stock return and classification of the risk of the country as a symptom of unpredictability of situations in the market.

O. E. Williamson proves that they are independent attributes, i.e. the limited rationality and behavior of the market participants orientated at seeking the opportunities, which are affecting the contractual relation due to the uncertainty and complexity of market situations, information asymmetry and existence of specific activities. The managing of agreements between the members of the distribution channel can lead managers to the endeavour to limit the effects of imperfectness of market and get inclined to a more advantageous organization of transactions within the more hierarchical context. As a result, such a relation can be internalized to be protected against possible negative impacts of unconditional attributes of transaction.

Transaction cost analysis perceives the behavior uncertainty because it originates from the problems connected with monitoring the effectiveness of contractual parties of exchange. The term behavior uncertainty is a level of difficulty connected with the evaluation of effectiveness of a transaction realized by the partners. The behavior uncertainty results from:

- limited rationality,

- behavior focused on seeking opportunities,

- information asymmetry.

Limited rationality presumes that the decision makers do not have sufficient consideration abilities (neuropsychological limits), or are limited in their considering on the basis of limited information sources whilst not necessarily having even sufficient communication abilities (communication limits). The resulting reaction to the environmental uncertainty is conforming to the problem, i.e. amendment of agreements with regard to the change of situation in the market. For example, a retailer, due to his access in a price competitive fight with another retailer, must modify the prices of the products he sells. Then the agreement between 
him/her and his/her retailer must specify the afore required product features and the relating sale conditions which must be respected by the producer, and at the same time it must foresee the important transaction costs connected with continuation of the agreement. Due to the influence of behavior uncertainty, there is a problem of evaluation of the agreement which means the problem of control if the contractual parties have kept it.

The behavior focused on seeking opportunities is characterized by the lack of honesty of managers who can make use of a specific situation in their favor. It results in the difficulty to recognize which partner is honest and which not. The behavior focused on seeking opportunities emphasizes the importance of specific assets which create contractual diversity of the subjects of the distribution channel. Their influence should create a protection against such behavior as the market competition is not sufficient to limit the behavior of this type.

In the information asymmetry, a retailer cannot differentiate the growth of costs connected with the unpredictable changes during the existence of the agreement (e.g. the increase in prices of raw materials input, wages, and the like) and decreasing the costs due to the supplier's effort and growth of his/her productivity. In connection with this, there is a morale risk which relates to the retailer's problems to recognize the development of total producer's costs at the time of negotiating the prices. According to the transaction cost theory it is necessary to avoid some transaction costs with the aim of their internalization within the hierarchical relationship.

\section{The purchasing department as a place of origin and development of relations between a retailer and his/her supplier as regards the transaction costs}

The first purchasing departments were started by retailers in cooperation with the farmers growing fruits and vegetables in the nineties of the 20th century. Since then the purchasing departments have been an important part of organization which maintains the power relations in the distribution channel (Lessassy 2007), whilst in the case of some retail chains they ensure as much as $90 \%$ of products for the large surface outlets and the remaining $10 \%$ is left for the regional purchasing departments with the aim of conforming the offer to the characteristics of the region which the retail outlet is located in. The value of the volume of purchase which they ensure represents several milliards of euro. For the producers with a limited budget they are the partners with an agreement on a preliminary listing in the supply chain.

On the one hand the rise of purchasing departments is connected with the approach aimed at a higher accessibility of a product in the market, and on the other hand it is connected with the transformation of food wholesale trade which has focused on reviewing the costs related to the coordination of activity but also the flexibility of its accommodating to the character of distribution under the conditions of saturated market and intensive competition where the customer is characterized by an unpredictable behavior. In these conditions the perspectives which exceed the goal of lowering the costs and concentrate on the issue of cooperation in the distribution channel must be taken into consideration (Fig. 2).

The diagram says the distribution channel lies more and more on the system of common values, in which the hierarchical system of relationship can be replenished or substituted by partnership between a producer and retailer. It results from a mutual reciprocity and responsibility of individual members of distribution for their roles fulfilled by them. This perspective is strengthened by a suggestion to create channels taking into consideration the creation of value for customers. At the same time there are the processes of specialization, learning and development of interorganisational competences which help understand these transaction costs from the point of view of dynamics of cooperation within the distribution of consumer goods.

The retrospective analysis of the cases of the retail chain Tesco which is the strongest retail chain having almost 16\% of the market (Sedlák, Kucejová 2010) makes it possible to illustrate the producer - retailer relations. The above mentioned retail chain is an example of a retailer whose relations with producers in the Slovak market belong to the most monitored and acute ones. The basis for analysis is also the published information on the communication of the chain Tesco with the public, the resources of the Ministry of Agriculture of the Slovak Republic, The Slovak Agricultural and Food Chamber, which replenish the context of the producer - retailer relations.

The selection of application to the case of milk can be reasoned by the specific situation in the Slovak market characterized by surplus of this product. The average price of bulk purchase of fresh cow milk by the manufacturer from the basic producer in February 2010 was $0.27 € / \mathrm{kg}$ excluding VAT (Májek 2010). The average price of bulk purchase in the year 2009 was $0.209 € / \mathrm{kg}$ excluding VAT (Kakulík 2009), being the lowest in the European Union which adds to the conflicts between the basic producers, producers of milk and retailers. The development of the milk price in the near future is presumed to stagnate.

\section{The use of the transaction cost theory in creation of new theoretical knowledge on the basis of analysis of the present situation in the producer - retailer relations}

The transaction cost theory is a suitable instrument for explaining the retailer - producer relations in the consumer goods market. On the one hand the transaction costs result from the human factor (opportunism in transactions, 


\begin{tabular}{|c|c|c|c|}
\hline $\begin{array}{l}\text { Creation of } \\
\text { strategies of } \\
\text { individual } \\
\text { partners as for } \\
\text { the power in the } \\
\text { distribution } \\
\text { channel } \\
\text { The dominant } \\
\text { position of } \\
\text { retailers } \\
\text { The require ments } \\
\text { of suppliers e.g. } \\
\text { farmers and the } \\
\text { like }\end{array}$ & $\begin{array}{l}\text { The rise of } \\
\text { distribution } \\
\text { channel as for } \\
\text { the value } \\
\text { creation } \\
\text { The sales and } \\
\text { creation of } \\
\text { a proper offer }\end{array}$ & $\begin{array}{l}\text { Selection of } \\
\text { organisation of } \\
\text { distribution channel } \\
\text { The informal system } \\
\text { of managing the } \\
\text { relation s with several } \\
\text { partners } \\
\text { The importance of } \\
\text { new models of } \\
\text { organising the } \\
\text { cooperation in the } \\
\text { distribution channel } \\
\text { as far as the } \\
\text { fle xibility and } \\
\text { development of } \\
\text { competences within } \\
\text { the normative and } \\
\text { social structure are } \\
\text { concerned }\end{array}$ & $\begin{array}{l}\text { The development } \\
\text { of purchasing } \\
\text { department } \\
\text { within the } \\
\text { distribution } \\
\text { channel }\end{array}$ \\
\hline
\end{tabular}

Resource: Lessassy, L. Pratiques des filières en grande distribution: une analyse par la théorie de transaction, Décisions Marketing [Marketing decisions] 15(46): 77-89 and our own processing of the issue

Fig. 2. The transaction cost theory and its role in creating the purchasing department within the distribution channel

information asymmetry and limited rationality), and on the other hand they are connected with the market environment of an enterprise (uncertainty, specific character of assets, frequency of transactions) (Anderson 1988).

The risks resulting from the environment of transactions between the milk producers and retail chains

The overproduction and instability of the market cause the repeated crisis situations between the local milk producers and retailers. The oligopolistic character of the Slovak consumer market, where there is only a small number of institutions, i.e. retail chains, creates a risk of uncompetitiveness of the milk market. The small producers who have bad experience in delivering to the large floor outlets are reasoning with the high rebates they have to commit themselves to. These results in a minimum margin on the sales of milk by the basic producer to the milk processor, which is reflected either in his/her refusal to produce milk or to sell it at the price not reaching the effectiveness threshold. The records on the sales of milk of the period of February and March 2010 (Májek 2010) show that the large floor outlets sell milk to the end user at the price of e.g. $0.50 €$ (Fig. 3), which is, as far as the basic consumer is concerned, 2.39 times higher than the price of the milk sold to the milk manufacturer, i.e. $0.209 €$. As far as the milk manufacturer is concerned the situation becomes even more complicated, because if the first delivery is realized at the price agreed on, as e.g. $0.36 €$, further deliveries are realized under the conditions when the purchasing departments are repeatedly trying to negotiate lower prices due to the requirements to pay the growth or logistic bonuses and the like. At the same time, in the situation when the milk does not sell as anticipated or in the quantities stated, the retail chains do not hesitate to turn to the supplier to recompense them for the lost profit on the quantity of products unsold (Sedlák, Kucejová 2010). This means that they are automatically made to lower the price of their products. These risks can be seen mainly in the cooperation with the producers who do not sell their products under the brand name of the retailer.

Similarly, the agreements between a producer and retailer do not allow foreseeing all possible situations which may occur, such as a surprising increase of demand, cheaper imports, the season, and the like. Similarly a retailer may be surprised by willful decisions of a producer which contradict with their mutual agreement. This concerns especially the producers who sell the product known and popular among end users. E.g. there is a conflict between Tesco and Coca-Cola as the products of a known producer were excluded from the assortment of the chain as the chain Tesco was buying more expensive products of a known drink producer than the chain Carrefour products (Pravda 2006). This fact 


\section{Distribution costs of the chain}

The buying price of 11 of milk is $0.209 €$ by the producer

The operating costs of the outlet: utilities, cleaning, supplementing the goods- $0.12 €$

Gross margin- $0.092 €$

VAT of $19 \%$ is $0.008 €$

\section{Distribution costs of producer}

The transport costs to the warehouses of the retail chain- $0.008 €$

The costs of taking over the goods to the warehouse, warehousing and transfer to the outlet-0.006 $€$

The charges of placement in the department: taking over and placement in the department-0.02 $€$

Contributions to the operation of the outlet: electricity, cleaning, supplementing the goods are $0.12 €$

The charges of non saled goods after expiration- $0.007 €$

\section{Transaction costs arising for both partners}

Creating values between a producer and retailer, i.e. the time and means related to the negotiation Checking the agreements

Selling price per $1 l$ of milk to the end users in the chain outlets $0.50 €$

Resource: our own processing of the issue

Fig. 3. The illustration example of forming the price per $1 l$ of milk for the end user

results in other consequences for both partners such as e.g. the problems in communication, lower trust, the differences between the requirements for the product quality and the real features of the product, breaking agreements which may lead to tremendous changes in prices and finally to the fear of placing another order by a retailer.

\section{Making the purchasing department taking part in the negotiations with a producer aimed at lowering the chain costs trying to reach the minimum price}

The knowledge of the milk production process makes it possible for retailers to decrease the distribution costs. At the same time the transaction costs connected with creating and control of agreements with the producer are getting lower.

If the process of forming the price of milk is analyzed from the point of view of accounting, all facts which have influence on the total selling price must be taken into consideration. As far as the producer is concerned the milk represents the inventory of own production which is created by own activity in the process of production. It means that on the basis of the Act No. 431/2002 Coll. as amended the producer must price the inventory of own production by a specific evaluating value -own costs. Thus the result of evaluating is the inventory evaluating itself, i.e. the quantification of the value of inventory. In addition to the profit, the price of milk includes the production costs of the milk producer which is a money form of expression of consumption of the production factors needed to produce milk.

Example 1 documents that the transaction costs are not included in the selling price of the end user as they arise in the process of other activities of both partners. In the same way we can follow the producer's distribution costs which he/she carries as the costs and they are related to his/her sales activity. These are the costs which are needed to sell his/her products or for the retail chain to be able to sell them to the end user at competitive prices. Even when a milk producer buys fresh milk from the basic manufacturer at $0.209 €$, he is made to sell his/her products at the minimum prices. That is why the milk producers who cooperate with the purchasing department of the chain require the selling price to be adequate to the value of the product.

When calculating the price of milk a producer must take into account all direct costs, indirect costs and profit. Calculating the cost this way it is possible to monitor the costs from different aspects as e.g. by the sorts, by the items of the calculating formula, by the place of origin, by the responsibility. For correct and complete calculating the cost for production of milk, the cost accounting uses a calculation formula which consists of several items: direct costs (direct material, direct wages, other direct costs) and overheads (production overheads, administration overheads, sales overheads). Adding the profit, the accounting entity can calculate the selling price per unit of milk. 
The costs of the accounting entity arising in connection with production of milk are of the character of variable costs or fixed costs. Fixed costs are relatively permanent even when the volume of milk production is changing (i.e. they are remaining of the absolute value - e.g. depreciation of buildings and production equipment is the same regardless the number of the units of milk produced). Variable costs are changing with regard to the volume of the milk produced as their accounting entity can calculate them per milk unit. The higher the volume of milk, the higher the amount of variable costs (direct material, direct wages) of the accounting entity.

The above mentioned shows more facts which the milk producer must take into account when forming the selling price of milk:

1. Direct costs of milk production must be included in the selling price. The direct costs are the packaging material and other material (food hydrogen peroxide, oil units and the like). It would not be possible to produce milk without these basic preconditions.

2. Direct wages of employees.

3. Other direct costs such as the costs of chemical analyses and analyses of the samples of the milk produced, and the like. These costs arise for the milk producer in connection with the process of milk production, therefore it is necessary to take them into account in the calculating formula.

4. Production overheads which are the costs necessary for a producer to be able to ensure the conditions suitable for the production process.

There is a question why a producer forms the selling price which is under the level of own costs?

One solution may be the subsidy by the government to cover the part of the costs which will result in the fact that the producer will not require the compensation of these costs by his/her buyers. Another possibility is that the producer has not deliberately included all his/her cost in the selling price and he/she deliberately gives up its compensation by the buyers. But from the long-term aspect this approach is economically liquidating (provided the milk producer does not use illegal financial sources). At the same time the producer does not keep the law on accounting which gives an exact defection of the cost. This means that evaluating the inventory of one's own production at the level of the cost is the right procedure which cannot be challenged by any arguments.

Another fact which must be taken into account is financing the milk producers' activities. It is a fact that most producers finance their activities using external resources paying no interest. The interest on credit is not included in the evaluation of the milk produced, even though in principle it is the cost caused directly by the production process (a producer would not draw the credit if he/she did not need to finance the milk production). Thus if the retail chains are active in influencing the level of selling price of milk it is really a symptom of a bad and unsound business environment which has nothing to do with the market economy.

At the same time a milk producer must take into account the situation in the market - the demand for milk, development of prices, and the like. He must also take this information into consideration in accounting to make his/her financial situation real. There may be a question how the accounting entity can express an anticipated decline of the consumers' demand for milk that may have an enormous influence upon the financial situation of the milk producer. In accounting the accounting entity carries the decline of the use value of the equity in the form of provisions debiting the cost account. A decreased demand for milk has an influence upon the change of price - it causes a temporary decline of the price of milk produced. Thus the accounting entity carries the costs which directly influence the financial result - this being a negative influence. If, in the next period, the price of milk is increased, the accounting entity can stop the provision, which means that the influence upon the financial result will be positive.

As far as the present producer - retailer relations are concerned, a retailer is trying to pay an excess value, which would recompense the price movement and the Endeavour of a producer to make a high quality product that, with regard to the yearly volume of purchase, would be always profitable keeping the prices agree upon. And this is possible due to the control of transactions.

Keeping the minimum price for the end user makes it possible for a retailer also to decrease the maintenance costs of contractual producers, who offer the possibility of realizing the activities necessary for the management of such an assortment as e.g. sales promotion, merchandising, education of consumers, and the like with the aim of better accommodating to the local specific features of the market.

The Table presents some solutions provided by the purchasing departments with regard to the market risks.

\section{Obstacles resulting from transaction costs}

The global competition and maturity of the Slovak market are substantially increasing the competitive conditions in the food market. Even though in the nineties of the 20th century when creating the purchasing departments the main interests of retailers were focused on the quantity of products and optimizing the logistic costs, at present other interests are being pushed forward which seem to be much more important in solving the problem of stagnation in the sales of food products. These interests can also be seen with competitors as far as the price and concentration of leaders in the distribution are concerned. New strategies have been reflected in the differentiation of a retailer, development of 
Table. The solutions provided by the purchasing departments with regard to the market risks

\begin{tabular}{l|l}
\hline The risk existing in the market & Purchasing departments of retail chains are providing solutions of risks \\
\hline Difficulty in forming the market price & $\begin{array}{l}\text { Process of allocation of internalized resources. A retailer is making remedy } \\
\text { via control }\end{array}$ \\
\hline $\begin{array}{l}\text { Costs to manage a dyadic relation resulting } \\
\text { from its centralization as far as the retailer is } \\
\text { concerned }\end{array}$ & $\begin{array}{l}\text { Rise of a structured system of communication and a hierarchical system in } \\
\text { the price decision making }\end{array}$ \\
\hline Opportunistic behavior of producers & Guarantee of a minimum price \\
\hline $\begin{array}{l}\text { Risk of manipulating the information: } \\
\text { deceiving, loss of competitiveness, loss of value }\end{array}$ & $\begin{array}{l}\text { Optimizing the product flows } \\
\text { Decentralization of supplying } \\
\text { Regional product management } \\
\text { Reducing the large number of intermediaries with the aim of switching } \\
\text { from several independent suppliers (long indirect distribution channels) to } \\
\text { a group of contractual producers with a retailer (short indirect distribution } \\
\text { channels) }\end{array}$ \\
\hline Limited rationality & Arranging exchange of information and trust between the partners \\
\hline
\end{tabular}

Resource: Rindfleisch, A.; Heide, J. B. Transaction cost analysis: past, present, and future application, Journal of Marketing 61(3): 30-54. Siguaw et al. Effects of supplier market orientation on retailer market orientation and the channel relationship: the retailer perspective, Journal of Marketing 62(2): 99-111 and our own processing

distribution channels of discounters, and the like. In this market context it is the price level as a criterion of selecting the place of purchase by the final user which a retailer is trying to show his distinction by.

Another important phenomenon of the relations between a producer and retailer is also the Act No. 172/2008 Col. on inadequate conditions in business relations and on the amendment of the Act of the Slovak National Council No. 30/1992 Col. on the Slovak Agricultural and Food Chamber amended which is trying to modify the conditions of the business relation between a supplier and his/her buyer while their being economically dependent on each other. Its inaccuracy is causing conflicts in the interpretations of individual contractual parties as far as the financial settlements and explanation of inadequate conditions are concerned. This results in the fact that a retailer knows the ways how to manage deliveries with the aim of avoiding unpleasant conditions not to offend his/ her suppliers cooperating with the purchasing department. In the case of milk it is a situation when cheap fresh milk is purchased e.g. in Poland while being processed in Slovakia.

\section{The duration of the life of agreements on partnership of a chain and a milk producer and the guarantee of the minimum price for the end user}

The problems connected with the present global economic crisis and the gradual revival of the economies of the countries in the world are also influencing duration of the life of the retailer - milk producer cooperation. The permanent character of production and the composition of milk are also creating an obstacle in seeking a long-term relationship between a purchasing department of the chain and a producer as there is a possibility of an easy replacement of a supplier. The exact keeping the contractual commitments resulting from an agreement signed emphasizes the maturity of a producer in his/her cooperation with a retail chain. A producer that does not sell the products under the retailer's own brand name is a risk for a short-term cooperation and he/she is also out of the retailer's control.

The market variations make it difficult to keep the minimum selling price for the end user while respecting the minimum production price of a milk producer which is connected with maintaining the effectiveness of a producer. In the case of a sudden fall of price for the end user, if there is a mutual competition fight of retailers, they do not hesitate to ask their suppliers to decrease the selling prices, which may lead to lowering the quality by producers. This situation evokes the considerations about the real value of agricultural products which is often a source of conflicts between individual members of the distribution channels. Even though a retailer has an argument of acceptability of the market price by the end user, according to the consequences resulting for the basic producers and processors of milk, such a reasoning of a low price is not considered useful. If there exists a milk producer - retailer partnership, a retailer is aware of the fact that he/she is buying a product with a guarantee of the minimum price, whilst both partners remain competitive and the end users benefit from buying the milk for a sustainable minimum price.

\section{Conclusion}

Thanks to the transaction cost theory the Endeavour to minimize costs makes it possible to understand the role of retail chains and their purchasing departments using different practices which, at first sight, seem to be hostile toward basic producers or milk producers but they have their 
grounds in the competition fight in the saturated milk market. Purchasing departments of retailers create institutional methods which help the reduction of costs with the aim of making the offer to end user more attractive using the means of long-term agreements with their suppliers thus making them create an offer on the basis of value. This is a new approach to making a producer's offer to his/her customer giving the end user a total benefit from the distribution channel.

The present development of the milk market environment makes a producer and retailer seek mutual advantage resulting from their cooperation which is reflected in the activity of purchasing departments. This means that the processes of learning, specialization and development of skills are a direction which makes the organizations understand the role of purchasing department in the milk distribution. The activity of the purchasing department created this way is of the meaning only if it respects the social context of retailer-supplier relations and their cooperation is based on agreements preferring the guarantee of minimum price.

Thus the selling price of milk is unequivocally limited by the bottom value and it cannot and should be not lower than that. To secure the economic stability of milk producer the selling price must cover all producers' costs. It is of course logical (with regard to the fact that milk producers are business people whose aim is to reach profit on their business activity) that the profit should be included in the selling price. This means that an ideal level of the selling price of milk is above the cost level.

\section{References}

Act No. 172/2008 Col. on Inadequate Conditions in Business Relations and on the amendment of the Act of the Slovak National Council No. 30/1992 Col. on the Slovak Agricultural and Food Chamber as amended.

Act No. 431/2002 Col. on Accounting as Ammended.

Anderson, E. 1988. Transaction costs as determinants of opportunism in integrated independent sales forces, Journal of Economic Behavior and Organization 9(2): 247-264. http://dx.doi.org/10.1016/0167-2681(88)90036-4
Baudry, B. 1995. L'économie des relations interentreprisep. 1 edition. Paris: Édition La Découverte. 121 p.

Directive of the Ministry of Finance of the Slovak Republic of 16 December 2002 No. 23054/2002-92, stipulating the details in the process of accounting and the Framework of the Chart of Accounts for the entrepreneurs accounting in double entry accounting as amended.

Grznár, M.; Szabo, L.; Jankelová, N. 2009. Agraring sector of the Slovak Republic after the entry to the European Union, Journal of Economics 57(9): 903-917.

Heide, J. B. 1994. Interorganizational governance in marketing channel, Journal of Marketing 58(1): 71-85. http://dx.doi.org/10.2307/1252252

Kakulík, D. 2009. The predictions of milk prices are optimistic, Agromagazín [Agromazine] 11(6): 11.

Lessassy, L. 2007. Pratiques des filières en grande distribution: une analyse par la théorie de transaction, Décisions Marketing [Marketing decisions] 15(46): 77-89.

Májek, M. 2010. New year began to fall in this stock market, Agromagazín [Agromagazine] 12(2): 31-33.

Pravda. 2006. Coca-Cola a Tesco sa kriepia o ceny [online], [cited 27 February 2006]. Available from Internet: http:// spravy.pravda.sk/coca-cola-a-tesco-sa-skriepia-o-ceny-dtk-/ sk_ekonomika.asp?c=A060227_102714_sk_pspravy_p01

Rindfleisch, A.; Heide, J. B. 1997. Transaction cost analysis: past, present, and future application, Journal of Marketing 61(3): 30-54. http://dx.doi.org/10.2307/1252085

Rosembloom, B. 1999. Marketing Channels. 6 edition. Fort Worth: Hardcourt College Publishers. 688 p. ISBN 0-03024482-X.

Sedlák, J.; Kucejová, V. 2010. Tesco: sales will remain, I believe that the food producers will agree with, Pravda [online], [cited 15 April 2010]. Available from Internet: http://peniaze. pravda.sk/tesco-akcie-zostanu-verim-ze-sa-s-potravinarmidohodneme-pea-/sk-pspotrebitel.asp?c=A100314_233405_skpspotrebitel_p45

Siguaw, J. A.; Simpson, P. M.; Baker, T. L. 1998. Effects of supplier market orientation on retailer market orientation and the channel relationship: the retailer perspective, Journal of Marketing 62(2): 99-111. http://dx.doi.org/10.2307/1251746

Jaroslav KITA. Prof., PhD in Marketing (University of Economics in Bratislava), lecturer at University of Economics in Bratislava. Research interests: marketing, customer behaviour in industrial market, relationships client-supplier, the buy and sell in industrial market.

Katarína MÁZIKOVÁ. Assoc. Prof., PhD in Accounting and Audit (University of Economics in Bratislava), lecturer at University of Economics in Bratislava. Research interests: legislative aspects influencing the accounting and audit, harmonization of accouting, creation and running of trade companies from the point of view on the accounting, international accounting standards.

Marta GROSSMANOVÁ. Assoc.Prof., PhD in English language (University of Economics in Bratislava), lecturer at University of Economics in Bratislava. Research interests: lexicology, linguistics, negotiation, intercultural communication.

Pavol KITA. Assoc. Prof., PhD in Marketing (University of Economics in Bratislava), lecturer at University of Economics in Bratislava. Research interests: marketing, consumer behaviour, merchandising, techniques of sales, personal sales, sensory marketing. 